\title{
PENGARUH KESELAMATAN, KESEHATAN DAN KEDISIPLINAN KERJA TERHADAP KINERJA KARYAWAN BAGIAN WORKSHOP PT. IRADAH DELAPAN
}

\author{
MUHAMMAD ROM RAFSANJANI ROMADHON \\ Progam Studi Manajemen \\ Fakultas Ekonomi- Universitas Muhammadiyah Gresik \\ Jl. Sumatra No. 101 GKB Gresik 61121 Jawa Timur Indonesia
}

\begin{abstract}
ABSTRAK
Upaya untuk meningkatkan kualitas sumber daya manusia, sumber utama perusahaan manusia perlu dilakukan dengan baik, terarah, dan terencana, sehingga perusahaan dapat bersaing secara adil dengan perusahaan lain, mengingat persaingan masa depan antar perusahaan akan semakin ketat. Sumber daya manusia mampu bersaing dengan pesaing atau dengan mitra bisnis satu-satunya perusahaan yang memiliki kualitas sumber daya manusia. Tujuan penelitian adalah untuk mengetahui pengaruh keselamatan kerja, kesehatan dan disiplin kerja terhadap kinerja karyawan PT. Divisi Workshop Iradah Delapan. Penelitian ini menggunakan metode survei dengan menggunakan data primer yang diperoleh dari kuesioner. Sampel dalam penelitian ini adalah 57 PT. Divisi Workshop Iradah Delapan. Sampel diambil menggunakan sampling jenuh adalah teknik sampling berdasarkan jumlah populasi keseluruhan. Data dianalisis menggunakan regresi linier berganda. Hasil penelitian menunjukkan bahwa: (1) Keselamatan Kerja berpengaruh positif signifikan terhadap kinerja karyawan. (2) Pekerjaan Kesehatan tidak ada efek yang signifikan berpengaruh positif terhadap kinerja karyawan. (3) Disiplin efek positif yang signifikan terhadap kinerja karyawan.
\end{abstract}

Kata kunci: Keselamatan Kerja, Kesehatan Kerja, Disiplin Kerja

\section{PENDAHUUAN}

Dalam suatu perusahaan, faktor karyawan merupakan salah satu hal yang penting untuk diperhatikan. Dengan adanya karyawan, suatu perusahaan dapat melaksanakan proses produksi atau manufaktur yang berguna untuk keberlangsungan perusahaan. Karyawan dalam suatu perusahaan dapat dikatakan sebagai faktor internal yang mana ketika kinerja mereka dalam status baik, maka output yang mereka hasilkan akan memuaskan dan tentu akan menguntungkan bagi perusahaan. Kinerja sendiri adalah hasil seseorang secara keseluruhan selama periode tertentu didalam melaksanakan tugas, seperti standar hasil kerja, target atau sasaran atau kriteria yang telah ditentukan terlebih dahulu dan telah disepakati bersama (Rivai dan Mohd Basri 2005,14).

PT. Iradah Delapan sebagai perusahaan dalam bidang jasa pengelasan menjadi salah satu perusahaan yang perlu mengetahui hasil kinerja karyawannya. Sesuai dengan manfaat adanya penilaian kinerja, maka dengan diketahui kelebihanataupunkekurangankinerja karyawan tersebut, akan dapat membantu evaluasi dalam menentukan kebijakan selanjutnya. Dari fenomena yang terjadi di PT. Iradah Delapan, dapat diketahui telah terjadi penurunan jumlah kuantitas. Penurunan kuantitas tersebut dapat diketahui dari total jumlah pengelasan yang selanjutnya dapat dinyatakan dalam satuan jumlah Joint. Pada kuartal pertama PT Iradah delapan dapat melaksanakan pengelasan sebanyak 202 Joint kemudian disusul kuartal ke dua yang mengalami penurunan jumlahnya yakni sebanyak 135 joint dan, terjadi penurunan kembali pada kuartal ke tiga yakni sebanyak 124 joint.

Fenomena lain yang perlu menjadi perhatian dalam kinerja adalah kualitas, kualitas dalam hal ini merupakan hasil kesempurnaan pengelasan. Kualitas yang dihasilkan kemampuan karyawan tersebut dapat dikatakan baik ketika tidak terjadi cacat atau kebocoran sambungan pada titik pengelasan sehingga tidak dilakukan proses perbaikan atau dapat disebut proses repair. Dari data repair PT. Iradah Delapan, dapat diketahui selalu terjadi proses repair pada setiap kuartalnya. Pada kuartal pertama terdapat repair sebanyak 23 joint dengan prosentase sebesar $11,4 \%$. Kemudian pada kuartal kedua terdapat repair sebanyak 17 joint dengan prosentase sebesar $12,6 \%$. Dan pada kuartal ke tiga terdapat repair sebanyak 16 joint dengan prosentase sebesar 12,9\%. Meskipun kuantitas dalam beberapa kuartal mengalami penurunan, namun prosentase perbaikan pada setiap kuartal tersebut diketahui mengalami kenaikan. Prosentase tersebut mengindikasikan perlunya evaluasi kinerja karyawan terhadap fenomena kualitas sendiri bisa dipengaruhi oleh banyak 
hal, dalam penelitian Kurnia (2010) dengan judul pengaruh karakteristik pekerjaan, disiplin kerja dan lingkungan kerja terhadap kinerja karyawan pada bagian produksi, menyatakan terdapat pengaruh antara karakteristik pekerjaan, disiplin dan lingkungan kerja terhadapkinerja

Selain itu, dalam penelitian lainnya Ilfani (2013) dengan judul analisis pengaruh keselamatan dan kesehatan kerja terhadap kinerja karyawan,juga menyatakan keselamatan dan kesehatan berpengaruh terhadap kinerja.Jadi dapat diketahuibeberapa hal yang berpengaruh terhadap kinerja adalah karakteristik pekerjaan, disiplin, lingkungan kerja, keselamatan dan kesehatan kerja.Namun dalam beberapa teori karakteristik dan likungan kerja merupakan bagian dari indikator keselamatan dan kesehatan kerja. Seperti yang diungkapkan oleh Mangkunegara (2016) menurut beliau ada beberapa indikator yang memungkinkan terjadinya kecelakaan dan gangguan kesehatan pegawai yakni, keadaan tempat lingkungan kerja, pengaturan udara, pengaturan penerangan, pemakaian peralatan kerja, kondisi fisik dan mental pegawai. Teori lainnya menurut Dessler (2009, 278) dalam bukunya Manajemen Sumber Daya Manusia, indikator penyebab utama kecelakaan adalah seperti peralatan yang tidak terjaga dengan baik, peralatan yang rusak, prosedur berbahaya disekitar mesin atau peralatan, penyimpanan yang tidak aman, penerangan yang tidak tepat dan ventilasi yang tidak baik. Dari teori tersebut dapat disimpulkan bahwa karakteristik pekerjaan dan lingkungan kerja merupakan bagian dari keselamatan dan kesehatankerja.

Beberapa hal lain yang juga diterapkan pada PT Iradah Delapan adalah mengenai kedisiplinan. Kedisiplinan kerja adalah sikap kejiwaan dari seseorang atau kelompok orang yang senantiasa berkehendak untuk mengikuti atau memenuhi segala aturan atau keputusan yang telah ditetapkan (Sinungan2003).

Dari 57 Karyawan pada Bagian Workshop setiap bulan pasti ada yang terlambat maupun tidak masuk kerja. Berdasarkan data grafik absensi karyawan pada PT. Iradah Delapan, dapat diketahui pada bulan Januari sampai bulan Juni 2016 selalu ada ketidak hadiran karyawan dengan Alpha (tanpa keterangan). Pada bulan januari hingga maret terdapat trend penurunan, yakni Januari sebanyak 12 orang ke bulan Maret menjadi 4 orang. Pada bulan berikutnya tingkat ketidak hadiran alpha mengalami kenaikan kembali yakni pada bulan april sebanyak 8 orang dan pada bulan mei sebanyak 10 orang.

Menurut Soejono (2000) disiplin kerja perusahaan atau instansi dapat dikatakan baik ketika tepat waktu, tepat dapat diartikan bahwa tidak ada selisih sedikitpun, tidak kurang dan lebih, persis. Sedangkan waktu adalah serangkaian saat yang telah lewat, sekarang, dan yang akan datang berdasarkan pengertian tersebut dapat ditarik kesimpulan bahwa ketepatan waktu adalah hal keadaan tepat tidak ada selisih sedikitpunbilawaktuyangditentukan tiba. Tujuan disiplin adalah untuk mendorong karyawan berperilaku hati-hati dalam pekerjaan (berhati- hati didefinisikan sesuai peraturan dan perundang-undangan). Dalam suatu organisasi, peraturan dan perundang undangan memiliki tujuan yang sama dengan apa yang dilakukan oleh hukum dalam masyarakat, dilanggar (Dessler 2009; 194)

\section{Rumusan Masalah}

1. Ada pengaruh Positif Keselamatan terhadap kinerja karyawan bagian workshop PT. Iradah Delapan.

2. Ada pengaruh Positif Kesehatan terhadap kinerja karyawan bagian workshop PT. Iradah Delapan.

3. Ada pengaruh Positif Kedisiplinan terhadap kinerja karyawan bagian workshop PT. IradahDelapan.

\section{Gambar 1.1 Rerangka Pemikiran}

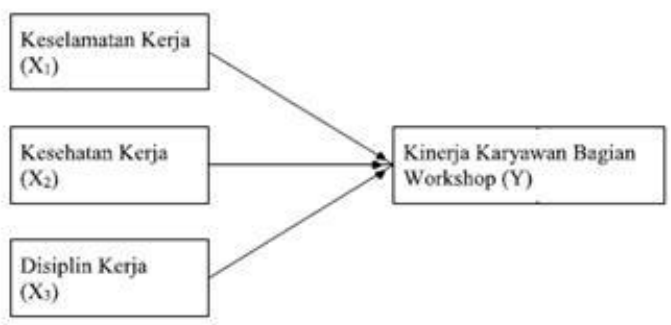

\section{METODE PENELITIAN}

Populasi adalah daerah generalisasi yang akan dikenai kesimpulan hasil penelitian. Hadi (2006, 70) mengatakan bahwa populasi merupakan sejumlah individu yang setidaknya mempunyai satu ciri atau sifat yang sama. Dari polulasi ini diambil contoh atau sampel yang diharapkan dapat mewakili populasi serta memberikan batas - batas yang jelas. Dalam penelitian ini populasi yang diambil adalah seluruh Karyawan PT. Iradah Delapan bagian Workshop yang berjumlah 57 orang

Sampel menurut Sugiyono (2010;116) adalah bagian dari jumlah dan karakteristik yang dimiliki oleh populasi. Metode penarikan sampel dalam penelitian ini adalah metode sampling jenuh yaitu teknik penentuan sampel bila semuaanggota populasi digunakan sebagai sampel. Istilah lain sampel jenuh adalah sensus, dimana semua anggota populasi dijadikan sampel. Sampel dari penelitian ini adalah 
karyawan pada bagian Workshop yang berjumlah 57orang.

\section{Definisi Variabel}

1. Variabel Keselamatan Kerja (X1) merupakan perlindungan terhadap kesejahteraan fisik seseorang terhadap cedera yang terkait dengan pekerjaan. Tanggapan responden mengenai keselamatan karyawan bagian workshop PT. Iradah delapan diketahui dengan indikator:

a. Peralatan yang terjaga dengan baik.

b. Prosedur berbahaya di dalam, pada, atau disekitar mesin atau peralatan.

c. Penyimpanan yang tidak aman (Kepadatan, kelebihan beban).

2. Variabel Kesehatan kerja (X2) merupakan perlindungan karyawan dari kemungkinan terkena penyakit atau keracunan dan usaha menjaga kesehatan fisik serta perhatian terhadap kemungkinan karyawan memperoleh ketegangan atau tekanan selama mereka bekerja. Tanggapan responden terhada kesehatan diketahui dengan indikator sebagai berikut:

a. Pengaturan Udara adalah pergantian udara di ruang kerja yang tidak baik. ( Ruang kerja yang kotor, berdebu, dan berbau tidak enak)

b. Pengaturan Penerangan merupakan pengaturan dan penggunaan sumber cahaya yang tidak tepat ( ruang kerja yang kurang cahaya, remang-remang)

3. Variabel Kedisiplinan Kerja (X3) Merupakan tanggapan responden terhadap kedisiplinan kerja yang diberlakukan oleh perusahaan. Tanggapan responden tersebut terkait dengan program kedisiplinan apa saja yang diterima oleh karyawan, dengan indikator variabel sebagai berikut:

a. Ketepatan waktu meliputi ketepatan jam pulang, ketepatan jam masuk, kepatuhan pada jam kerja.

b. Kesetiaan atau patuh pada peraturan dan tata tertib yang ada, meliputi kepatuhan untuk memakai seragam dan kepatuhan terhadap peraturan tatatertib dan komitmen yang telah disepakati.

c. Mempergunakan dan memelihara peralatan kerja.

4. Kinerja(Y) merupakan tanggapan Foreman terhadap Kinerja yang diberikan karyawan. Tanggapan tersebut terkait dengan kinerja karyawan sesuai dengan teori kinerja karyawan secara individumenurut (Robbins 2006, 260) yang dikutip dari
(Muadlomah 2016, 30). Dengan mengeliminasi satu indikator yakni kuantitas yang tidak memungkinkan untukdinilai secara individu, karena kuantitas merupakan hasil kerja tim pada bagian workshop PT Iradah Delapan. Maka indikator kinerja dikerucutkan menjadi:

d. Kualitas kerja meliputi hasil ketepatan dan keberhasilan.

e. Ketepatan waktu dalam menyelesaikan pekerjaan.

f. Efektifitas merupakan tingkat penggunaan sumber daya organisasi (tenaga, uang, teknologi, bahan baku) dimaksimalkan dengan maksud menaikkan hasil dari setiap unit dalam penggunaan sumberdaya.

g. Kemandirian merupakan tingkat seorang karyawan yang nantinya akan dapat menjalankan fungsi kerjanya serta komitmen dan tanggung jawab terhadap instansi.

\section{METODE PENELITIAN}

Teknik pengambilan data penelitian ini dengan metode angket (kuesioner). Kuesioner yaitu memperoleh data dengan cara mengajukan daftar pertanyaan tertulis secara lengkap tentang masalah yang akan dibahas, mengenai Keselamatan kerja, Kesehatan kerja dan Kedisiplinan terhadapkinerja Karyawan.

\section{HASIL DAN PEMBAHASAN Uji Validitas \& Reliabilitas \\ Uji Validitas}

Hasil dari uji validitas instrumen semua variabel didapatkan rhitung> rtabel 0,2610. Jadi seluruh butir pernyataan / indikator dari variabel independen maupun dependen terbukti valid dan mampu menjelaskan variabel independen maupun dependentersebut.

\section{Reliabilitas}

Masing-masing variabel nilai nilai Cronbach Alpha lebih besar dar i0,70. Dengan demikian dapat disimpulkan bahwa alat ukur yang digunakan dalam penelitian ini adalah reliabel.

\section{Analisis Uji AsumsiKlasik}

Uji Autokorelasi

Dari hasil pengolahan data di dapatkan nilai Durbin Watson sebesar 1.790. Dengan $k=3$ dan $\mathrm{n}=57$ makadi dapatkan nilai $\mathrm{dL}=1.463$ dan $\mathrm{Du}=1.684$. Ini berarti nilai Durbin Watson berada diantara Du dan4 -DU yang berarti tidak ada autokorelasi. 


\section{UjiMultikolinearitas}

Hasil pada uji multikolineritas di dapatkan nilai Tolerance pada statistik kolinieritas untuk variabel Keselamatan Kerja mencapai 0.754, Kesehatan Kerja mencapai 0.543 dan Kedisiplinan Kerja mencapai 0.685. Sementara dari nilai VIF untuk variabel Keselamatan Kerja sebesar 1,326, Kesehatan Kerja sebesar1,843 dan Kedisiplinan Kerja sebesar1,459. Batas terjadinya multikolinieritas apabila nilai VIF lebih dari 10 , atau nilai tolerance lebih kecil dari 0.1 , sesuai hasil diatas dimana nilai VIF tidak melebihi 10 atau tolerancetidak ada yang kurang dari 0,1 maka disimpulkan tidak ditemukan gejala kolinieritasganda.

\section{Uji Heteroskedastisitas}

Uji ini untuk memastikan bahwa variabel bebas tidak berhubungan secara signifikan dengan error prediksi dari model regresi. Dari hasil pengujian asumsi homokedastisitas melalui grafik scatter plot pada residual diperoleh hasil bahwa grafik menunjukkan titik-titik observasi tersebar acak dan tidak membentuk suatu pola tertentu. Sehingga dapat disimpulkan bahwa tidak ada masalah

\section{Uji Normalitas}

Nilai Z Kolmogorov-Smirnov maupun dengan melihat p-value(sig.) menunjukkan kesimpulan bahwa sebaran residual mengikuti pola distribusi normal.Nilai p-value (asymp.Sig.) telah melebihi batas kritis 0.05 dengan demikian $\mathrm{H} 0$ diterima, yang berarti sebaran data yang diuji tidak berbeda secara signifikan dengan pola distribusi normal yangsesungguhnya.

\section{Analisis Data}

Analisis Regresi Linear Berganda

$\mathrm{Y}=3.328+0.594 \mathrm{X} 1+0.024 \mathrm{X} 2+0.421 \mathrm{X} 3+\mathrm{e}$

Model diatas dapat dijelaskan dan dijabarkan pengaruh dari masing- masing variabel dalam model.

1. Konstanta $(\alpha) \quad$ sebesar 3.328 Besarankonstantadalammodelini sebesar 3.328 menjelaskan bahwa ketika variabel bebas Keselamatan Kerja, Kesehatan Kerja, dan Kedisiplinan Kerja sebesar nol, tampak tingkat kinerja karyawan yang dimiliki sebesar3.328.

2. Koefisien Keselamatan $\operatorname{Kerja}(X 1)$ sebesar0.594 Koefisien kedisiplinan kerja sebesar 0.594 yang menunjukkan bahwa setiap perubahan yang terjadi pada variabel keselamatan kerja (X1) untuk tiap satuannya akan menyebabkan perubahanatau berpengaruh positif terhadap variabel kinerja karyawan (Y) sebesar 0.594 dengan asumsi variabel lainkonstan.

3. Koefisien Kesehatan Kerja (X2) sebesar 0.024 , Koefisien kesehatan kerja sebesar 0.024 yang menunjukkan bahwa setiap perubahan yang terjadi pada variabel kesehatan kerja (X2) untuk tiap satuannya akan menyebabkan perubahan atau berpengaruh positif terhadap variabel kinerja karyawan (Y) sebesar 0.024 dengan asumsi variabel lain konstan.

4. Koefisien Kedisiplinan Kerja (X3) sebesar0.421 Koefisien kedisiplinan kerja sebesar 0.421 , menunjukkan bahwa setiap perubahan yang terjadi pada variabel kedisiplinan kerja (X3) untuk tiap satuannya akan menyebabkan perubahanatau memiliki pengaruh positif terhadap variabel kinerja karyawan (Y) sebesar 0.421 dengan asumsi variabel lain konstan

\section{Koifisien Determinasi (R2) dan Koefisien Korelasi Ganda}

Hasil pada tabel model regresi linier berganda diketahui nilai koefisien korelasi berganda (R) sebesar 0,657.hal menjelaskan keeratan hubungan antara model prediksi dengan motivas kerja menunjukkan bahwa mode yang terdiri dari keselamatan kerja (X1), kesehatan kerja (X2) dankedisiplinan kerja (X3) mempunyai hubungan terhadap kinerja karyawan (Y) sebesar $65,7 \%$.

\section{Uji Hipotesis}

\section{Uji t (Parsial)}

1. Variabel Keselamatan Kerja (X1) Hasil perhitungan uji $\mathrm{t}$ didapatkan nilai $\mathrm{t}$ hitung sebesar 4,196 yang berarti lebih besar dari nilai ttabel sebesar 1,674. Kemudian pada nilai signifikansi didapatkan nilai sinifikansi sebesar 0,000 yang

berarti lebih kecil dari nilai $\alpha(0,05)$. Dari hasil tersebut dapat diketahui bahwa $\mathrm{HO}$ ditolak dan $\mathrm{H} 1$ diterima, hal ini berarti bahwa keselamatan kerja terbukti mempunyai pengaruh signifikan terhadap kinerja karyawan bagian workshop di PT IradahDelapan.

2. Variabel Kesehatan Kerja (X1) Hasil perhitungan uji $\mathrm{t}$ didapatkan nilai $\mathrm{t}$ hitung sebesar 0,124 yang berarti lebih kecil dari nilai t tabel sebesar 1,674. Kemudian pada nilai signifikansi didapatkan nilai sinifikansi sebesar 0,901 yang berarti lebih besar dari nilai $\alpha(0,05)$. Dari hasil tersebut dapat diketahui bahwa H0 di terima dan H2 ditolak, hal ini berarti bahwa kesehatan kerja tidak terbukti mempunyai 
pengaruh signifikan terhadap kinerja karyawan bagian workshop di PT IradahDelapan.

3. Variabel Kedisiplinan Kerja (X1) Hasil perhitungan uji $\mathrm{t}$ didapatkan nilai t hitung sebesar 2,594 yang berarti lebih besar dari nilai ttabel sebesar 1,674. Kemudian pada nilai signifikansi didapatkan nilai sinifikansi sebesar 0,012 yang berarti lebih kecil dari nilai $\alpha(0,05)$. Dari hasil tersebut dapat diketahui bahwa $\mathrm{H} 0$ ditolak danH3 diterima, hal ini berarti bahwa kedisiplinan kerja terbukti mempunyai pengaruh signifikan terhadap kinerja karyawan bagian workshop di PT IradahDelapan.

\section{KESIMPULAN}

\section{Kesimpulan}

1. Variabel Keselamatan Kerja berpengaruh positif terhadap variabel KinerjaKaryawan (Y) bagian workshop padaPT. IradahDelapan

2. Variabel Kesehatan Kerja tidak berpengaruh terhadap variabel Kinerja Karyawan (Y) bagian workshop pada PT. Iradah Delapan.

3. Variabel Kedisiplinan Kerja berpengaruh positif terhadap variabel KinerjaKaryawan (Y) bagian workshop pada PT. Iradah Delapan.

\section{Saran}

Bagi perusahaan dan manajemen PT. Iradah Delapan, diharapkan dapat mempertahankan serta melakukan pembaharuan prosedur pada keselamatan, kesehatan dan Kedisiplinan sesuai dengan temuan yang ada. Dalam hal keselamatan karyawan, pembaharuan dapat saja dilakukan dengan penerapan standart operating

\section{DAFTAR PUSTAKA}

Desler, Garry, 1997. Manajemen Sumber Daya Manusia, Jakarta: PT. Prenhallindo

Gempur, Santosa, 2004, Pemikiran Setiap

Kecelakaan Pasti Ada Sebabnya, Jakarta: Prestasi Pustaka

Ghozali, Imam, 2013. Analisis PengaruhKeselamatan dan Kesehatan Kerja Terhadap Kinerja Karyawan (Studi Kasus PT. Apac Inti Corpora Bawen Jawa Tengah Unit Spinning 2), Semarang

Kurnia, Dyta. 2010. Pengaruh Karakteristik

Pekerjaan Disiplin Kerja

Lingkungan Kerja Terhadap

Kinerja Karyawan Pada Bagian Produksi di PT. Barata Indonesia Gresik. Gresik

Ranupandojo, H, dan Suad Hasan. 1984. Manajemen Personalia.

Yogyakarta.: BPFE

Rivai, Veithzal, dan Ahmad Fawzi Mohd Basri. 2005. Performance Appraisal

Sistem Yang Tepat Untuk Menilai Kinerja Karyawan Dan Meningkatkan Daya Saing Perusahaan. Jakarta: PT. Raja Grafindo Persada

Robbins, Stephen P. 2006. Perilaku Organisasi. Jakarta: Kelompok Gramedia

Siagian, Henry. 2005. Kiat Meningkatkan Produktivitas Kerja. Jakarta: PT. Rineka Cipta.

Simamora, Henry. 2005. Manajemen Sumber Daya Manusia. Jakarta: PT Aksara. Jakarta: PT. Bumi Aksara

Simanjutak, Payaman J. 2005. Manajemen dan Evaluasi Kerja. Jakarta : Lembaga Penerbit FE UI

Sinungan, M. 2003. Produktivitas Apa dan Bagaimana. Jakarta: Bumi Aksara

Sugiyono. 2008. Metode Penelitian Kuantitatif, Kualitatif, dan R\&D . Bandung : Alfabeta.

Suma'mur. 1998. Perusahaan dan Kesehatan Kerja. Jakarta: CV. Haji Masagung

Sutrisno, Edy. 2009. Manajemen Sumber Daya Manusia. Vol 1 Jakarta : Kencana 